\title{
L. On the food of plants
}

\section{Rev. Joseph Townshend}

To cite this article: Rev. Joseph Townshend (1807) L. On the food of plants, Philosophical Magazine Series 1, 26:104, 317-328, DOI: 10.1080/14786440708563681

To link to this article: http://dx.doi.org/10.1080/14786440708563681

$$
\text { 曲 Published online: } 18 \text { May } 2009 .
$$

Submit your article to this journal 전

III Article views: 2

Q View related articles $\asymp$ 
Mr. Woolf's improvement on the piston is such as to enable the engine-man to tighten the piston without the necessity of taking off the cover of the cylinder, except when new packing becomes necessary. He accomplishes this by either of the two following methods :

He fastens each of the screws into a small wheel $(c$, fig. 1 , and $c, c, c, c, c$, fig. 2. Plate VI.), which are all connected with each other by means of a central wheel $(d, d$,$) , which$ works loose upon the piston-rod in such a manner, that if one of the small wheels be turned, it turns the central wheel, and the latter turns the other four. The one that is to be first turned is furnished with a projecting square head, which rises up into a recess in the cover of the cylinder. This recess is surmounted by a cap or bonnet $e$ (Plate VI. and VII.), which being easily taken off, and as easily put again in its place, there is little difficulty in screwing down the packing at any time. The parts are so clearly expressed in the plates that no further description is necessary to make any person comprehend it.

The other method is similar in principle, but a little different in construction. (See Plate VII.) Instead of having several screws all worked down by one motion, there is in this but one screw, and that one is a part of the piston-rod: on this is placed a wheel of a convenient diameter, the centre of which is furnished with a female screw. This wheel is turned round, i.e. screwed down by means of the pinion 0,0 , which is furnished with a square projecting head rising into a recess of the kind already described. The ring is prevented from turning with the wheel by means of two steady pins.

L. On the Food of Plants. By the Rev. Joseph TownsHend, Rector of Pewsey, Wilts*.

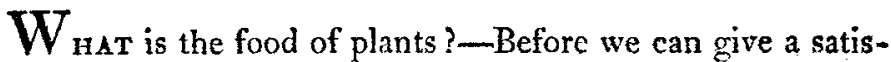
factory answer to this question we must collect facts, we must multiply experiments. For this purpose, in the years

- From Letters and Papers of the Bath Agricultural Society, vol. x. 
1792 and 1793 I put various seeds to vegetate in differens airs; in atmospherie air, in vital air, and in azote. The general result was, that neither wheat, oats, nor barley, vegetated in azote; but in vital air vegetation was uniformly rapid.

July 12, 1796, I placed eleven cabbage plants in pots, all healthy plants, and weighing each a quarter of an ounce apothecaries' weight. The pots stood in pans with water, and remained in them till June 12, 1797, when the plants were taken out of the pots and weighed again.

Of these pots four had quartz sand, washed clean, and rendered perfectly free from mixture of either argil or calcareous earth.

No. 1 . had nothing but this sand: the plant lived, but did not increase in bulk; when examined, the radical fibres were found numerous and extended, but very small ; and when the plant was weighed in January 1797, it had not increased in wcight.

No. 2. had the same kind of sand and woollen rags : the roots shot vigorously, the plant cabbaged, and in January 1797 weighed two onnees.

No. 3. had the same kind of sand, with about 1-4th part eharcoal in powder: the roots were less vigorous than the former, and in January 1797 the plant weighed 3-4ths of an ounce.

No. 4. had this sand with abont 1-20th lime. The plant did not increase, yet lived, and in January 1797 weighed only $3 \mathrm{dwts}$., have lost 2-5ths of its original weight.

No. 5. had brickmaker's clay alone: the plant lived, looked fresh, but in January 1797 weighed only half an ounce.

No, 6. had brickmaker's clay, with an equal proportion of the quartz sand. This plant, like the former, lived, looked fresh, and in January 1797 weighed half an ounce.

No. 7. had brickmaker's clay, with about 1-4th part charcoal in powder. In January 1797 the plant weighed half an ounce.

No. 8. had brickmaker's clay and woollen rags. This plant cabbaged well, and in January 1797 weighed four ounces. 
No. 9. had brickmaker's clay, with about 1-20th lime. The plant lived till December, but never grew.

No. 10. had clean dung from the bowels of a horse, with quartz sand well washed. This plant dropped some of its largest leaves during the frost, and yet in January 1797 it weighed $4 \frac{1}{2}$ ounces.

No. 11. had peat eartb alone: the plant continued healthy to appearance, and in January 1797 weighed half an ounce, but the root was rotted off.

No. 12. was planted at the same time in the garden, near the pots, in rich mould ; this did not drop any leaves, and in January 1797 weighed four ounces.

Such was the result of these experiments on cabbage plants. In January 1797, having removed the cabbage plants, I sowed wheat in the same pots; and 25th September of the same year I made the subsequent report :

No. 1, with quartz sand alone, had two sterns 23 inches long, and the ears $1 \frac{3}{4}$ inch.

No. 2, the sand and rags, had four stems 28 inches long, and the ears $2 \frac{1}{2}$ inches.

No. 3, the sand and charcoal, had one stem 18 inches long, and the ear $1 \frac{3}{4}$ inch.

No. 4, the sand and lime, had two stems 21 inches long, and the ear 2 inches.

No. 5, the clay alone, had three stems 27 inches long, and the ears $1 \frac{3}{4}$ inch.

No. 6 , the clay and sand, had four stems 25 inches long, and the ears $2 \frac{1}{2}$ inches.

No. 7 , the clay and charcoal, had four stems 24 inches, and the ears two inches.

No. 8 , the clay and rags, had twelve stems 33 inches long, and the ears $2 \frac{1}{2}$ inches.

No. 9, the clay and lime, had one stem, very slender, 15 inches, and the ear $1 \frac{3}{4}$ inch.

No. 10, the dung and sand, had sixteen stems 37 inches long, and the ears $2 \frac{3}{4}$ inches, very strong.

No. 11, the peat earth, had six stems 35 inches long, and the ears $2 \frac{1}{4}$ inches. 
Thus, it appears, that in both sets of experiments the results were similar.

From these facts, compared with other facts with which we are conversant, such as the flowering of bulbous roots in water, and more especially the vast increase of the withytree, recorded by Mr. Boyle, our attention is naturally turned in the first place to water, as the supposed nutriment of plants.

In the experiments before 119 , both the cabbage and the wheat of No. 1. were well supplied with water; but in the space of six months the former had not increased in either weight or bulk; and the latter, in eight months, produced only two miserable stems.

In Catalonia, more especially in the vicinity of Barcelona, the soil is principally quartz, from decomposed granite; yet being well watered, and plentifully supplied with light and beat, the crops of every kind are most abundant.

M. de Saussure remarks, that "we deceive ourselves exceedingly when we imagine that the fertility of any district depende wholly on the nature of its soil, because abundance and scarcity in crops arise principally from the degree of heat and humidity in the air with the quantity and quality. of the exhalations with which it is charged." $\mathrm{He}$ adds, "I have seen, in Sicily and Calabria, rocks and gravel arid and uncultivated, such as in Switzerland would have been altogether barren, which there produced more vigorous plants than are to be seen on the richest and best cultivated kands amongst the Helvetic mountains *."

It is astonishing to see, in a warm climate, the rapid growth of vegetables when they are wcll supplied with watcr. The smallest cutting of a vine will, in the space of fifteen or sixteen months, cover the front of an extensive edifice, or form a spacious habour from which the assembled family may gather in abundamce of the most luxuriant grapes. In such a situation the seeds of limes, oranges, and lemons, will, in four or five years, produce a shady grove; and mulberry trees, when wholly stripped of their leaves for the nu-

* Voyage dass leo Alpes, 131 .

triment, 
triment of silkworms, will again, in a few days, be covered thick with foliage.

Adanson, in his account of Senegal, informs us, that "when every thing green has been devoured by locusts, not a vestige of their destructive progress, after a few days, cain be discovered."

From the consideration of these and other facts similar to them, many distinguished chemists have delivered it as their opinion that water is decomposed by vegetables. M. Chaptal says, "La décomposition de l'eau est provivée non seulement dans le vegétal mais dans l'animal." And for this last he quotes the authority of Rondelet.

That water, as such, enters larely into the composition of vegetables, is evident; but whether or not, and to what extent, it is decomposed, has not, as I apprehend, theen yet demonstrated. In water meadows, with a plentifil supply of running water, vegetation procecds even in the depth of winter, and during the scverest frosts; but stagnant water is at all times unfriendly to our meadows. Any given quantity may remain upon the surface for weeks or nonths subject to decomposition; but instead of bcing in this state beneficial, it is injurious to our crops. In our water meadows we universally observe that it is not humidity which does good, but a thick sheet of water flowing incessantly, night and day, (for a certain period) over the surface.

Hence it seems probable that water is essential to the growth of plants, not merely as such, but as it proves a vehicle of other substances which are their proper food.

If we may form a judgment from their analysis, carbon may be regarded as the chief pahulum of plants; and this we know can, in a given proportion, be conveyed to them by water. M. Chaptal is not only of opinion that carbonic acid is essential to their growth, but he affirms that the base of this acid contributes to the formation of the vegetalle fibre. In support of this opinion he observes, that in fungi, which live in subterraneous places, this acid abounds; but by bringing them from almost perfect darkness gradually to the light, this acid disappears, and the fibres proportionably increase. This opinion is confirmed by some experinents Vol. 26. No. 104. Jan. 180\%. X of 
of M. Senebier, in which he observed, that "plants abun-o dantly supplied with water which had been impregnated with carbonic acid, transpired much more oxygen than when they "ere supplicd with common water."

Some plants take more carbon than others into thcir composition; as for instance, the Agaricus quercinus, Agaricus antiquas, Botctus versicolor, Boletus igniarius, Boletus striatus, Boletus perennis, Clararia hypoxylon, Clavrria pistillaris, and many others. Al! these contain, from the result of analysis, a quantity of carbon nearly equal to all their other component parts. But the Lichen crispus, Pinaster granulatus, and Lycoperdon tessellutum, contain a very small portion of carbon.

Plants do not, however, retain all the carbonaceous matter they receive; they obtain more in the day, when exposed to light, than they naturally require; but by the absence of light they part with this surplus, and therefore yield respirable gas only in the day-time.

The separation of oxygen from plants by radiant light, scems to arise from the chemical affinity between oxygen and light. For this fact we are indebted to Dr. Ingenhonz; but Humbolit was the first who ascertained that hydrogen gas applied to plants, even when excluded from the light, occasions a separation of their accumulated oxygen.

Some plants, as for instance tremella nostoc, the filices, musci, and algae, retain their oxygen weakly, and part with it readily. And it is remarked by Van Uslar, to whom I am indebted for many of these observations, that such plants as contain much oxygen, and retain it obstimately, are white; as for instance, our endive and cciery when excluded from the light; while such as contain much oxygen, and part with it easily, are generally green.

If the analysis of plants leads ts to consider carbon as one of the most essential articles in their composition and support, no less does the experience of ages prove to us that the principal source from which they derive thej nutriment, whatever it may be, is to be sought for in vegetable earth, the produce of animal and vegetable substances decayed. Many plants, indeed, require little or no earth for 
their regetation, such as the numerotis lichens and traghcanth, of whicin genera the former were disonvered by Satssure on the higest of the Alpme granite rocks. In lower situations these form a soul for the gentitia, for the cistuses, and more especially for rosimary and laternier, which abrand on the most elevated mountains of the Pyonnces. These again, by their decay, form vegctable carth, in which the luxuriant pine-trees and the lies grow.

This vegetable matier, being wahed down into the ralleys, helps to form and to increase lleir soil to a considerable depth, and to give them that fertility which is not readily exhausted.

When we analyse a soil, we never fail to find it composed of substances derived from a supcrior level. If the hills are quartzose, calcarcous, argillaceus, or magnesian, so is the soil in all the valleys which communicate with them. But with these earths in a rich soil we find a great proportion of vegetable matter, or of animal exuria ; and as these are deficient or abound, vegetation lauguishes, or is cxcecdingly luxuriant.

Good motid abounding with regetable maters is commonly of a dark colour, pulverises easily, and has therefore what is called a mellow look; but when exhausted or impoverished by ficquent crops, the richest soil, such as I have here described, becomes arid, of a lighter colour, compact, and comparatively barren. In a maiden soil, or where every shower of rain brings down from more elevated regions a quantity of vegetable matter, a succession of luxuriant crops may be taken uncessantly without any diminution of fertility. Thus it is in the country newly occupied by the Americans, in Kentucky, on the Ohio; and in the whole extent of territory watered by the Mississippi or by its tributary streams. Thus also in some parts of Spain, where an extensive plain happens to receive the spoils of rich circumjacent hills, as in the well-watered vale of Orihuela, near Murcia, of which they say, "Lct it rain or not rain, corn never fails in Oribuela." Indeed, so productive is wheat in that highly-faroured district, that the farasers commonly receive 100 for 1 upon their seed. 
In my experiments, No. 10, we see, by the luxuriant growth of the cabbage and the wheat, what vegetable matter can produce: for in neither of these could any kind of nutriment be derived from the quartz sand in which they spread their roots.

The same kind of sand in the vicinity of Barcelona is, by the assistance of a bright sun and copious irrigation, rendered exceedingly productive; hut then they spread upon the land all the dung they can procire, and not only station children and old women on the highways with little baskets to collect this manure as it falls from horses or from mules, but, like the farmers in the south of France, thcy pick the leaves from the trees in autumn, and this at a considerable expense. Of such importance do they consider vegetable matter as the food of plants.

It must be confessed that we have frequently occasion to obscrve plants dependant on the nature of the earth in which they are found, and affecting each its peculiar earth, in which they grow spontaneously and thrive.

Thus on chalky and calcareous soils we find Thesium $l i-$ noplyyllum, Antinyllis vulneraria, Asperula cynanchia, Lotus corniculatus, Hippocrepis comosa, Poa cristala; and thrce of the Sedums, the S. acre, S. allum, and S. reflexum; as on the Wiltshire downs, and on the hills round Bath.

On sand we see Arenuria, Rumex acetosella, and all the sorrels; the Plantago maritima, the Plantago Cornopus, the Onopordum Acanthium, the Sedum Anglicum, and most remarkably the Spartium scoparium.

On clay, if wet, the Carices, the Junci, Schonus, Aira cespitosa, and Aira coerulea, Orchis latifolia, and Orchis conobsed; if dry, the Primula veris, Orchis mas, Orchis maculata, and Poa pratensis.

On bogs, the Equiseta, Vaccinium uliginosum, Anagallis tenella, Scirpas palustris, Menyanthes trifoliata, and Drosera, delight to dwell.

On the sea shore, and wherever the muriatic salt abounds, as near Alicant in Spain, we find Salicornia Europeca, four species of Salsola, Chenopodium maritimum, and two species of Mesemliryanthemun. 
These maritime plants appear to decompose a part of the soil in which they grow; the alkali produced by burning them, or the sal soda used in glass and soap, is evidently derived by them from the muriatic salt.

But when we see the Lichen partllus fixing itself on the siliceous rock, or the Lichen immersus affecting as it does the calcareous rock in preference to the siliceous; whatever may influence this choice, we cannot suspect that either of these rocks contributes by its ciecomprsition to the nutrition of these plants ; nor, as I apprehend, have we reason to imagine that either chalk, sand, or clay, are in any form the aliment of the plants.

Woollen rags have been found of great utility as a manure, more especially for wheat. And in the experiments before us we may observe, that sand with rags produced a cabbage of two ounces, and four strong ears of wheat. In clay with rags our cabbage weighed four ounces, and we had twelve strong ears of wheat. But in what manner these rags produced effect it is difficult to say, for in January 1797 they were not visibly decayed; and in the month of September in that year they still retained their texture. The quantity we usually spread upon one acre is not more than four or five cwt.; and yet in the experience of every farmer it is found that in the first year they nearly double the crop of wheat, and in the two succeeding years they yielded a visible increase. At present, therefore, we can merely record it as a fact, that woollen rags are bighly beneficial to the land : but we cannot pretend to say by what process they contribute to the nutriment of plants.

Lime in our experiments was clearly detrimental with sand; the cabbage lived, but weighed less in January than when planted in July: the wheat had two slender stems. In clay with lime our cabbage lived till December, but never grew. The wheat had one stem, which was extremely slender, and the ear was diminutive.

These facts appear discordant with the experience of farmers in every quarter of the globe; for lime is found to be an excellent manure. In some parts of Wales they have $\mathrm{X} 3$ scarcely 
scarcely any other dressing for their wheat. I well remem. ber, that in the parish of Lansamlet, ix Glamorganshire, my father, who was very attentive to agriculture, put most of his stable dung on meadow land, and used only lime for wheat. He had two lime-kilns constantly burning for his own use, and with this manure he obtained the most abundant crops; but then his land was principally a dark vegetable mould, and much of it was peat, which before it was drained had becn a bog. On this land I have counted sixty grains to an ear, not picked and culler out of many others as being longer than the rest, but taken by handsful at random.

In his land, lime as a dressing was particularly apt, becanse, as we know, it hastens the putrefactive process, and promotes the dissolution of vegetabie substances, couverting them quichly into regetable mould.

Now in my expriments there was no vegetable matter to be dissolved, and therefore no benefit, according to chemical principles, was to be expected from the lime. The trial was however made, and the receicel opinion as to the effect of lime is thus far confirmed.

But in my experiments the line appears to lare been deleterious. This was not from its cansticity, for the plants lived; but from its action as a cement in forming a crust on the surface of the pots impervions to air. Fur in these pots I remarked, that after rain the water staguated, and did not rearily pentiate as in the other pots.

Free access of air to the roots of plants seems to be of vast importance, and almost essential to their guw th. With regard to seeds, access of air is absolutely needfinl to their vegetation. Hence it is that charlock (Sinapis artensis) will remain in the carth for centuries, if deposited below the regetating distance, as we have nccasion to observe on Salis bury plain, where no charlock is ever seen, unless when the downs are broken up. The land is then covered with it; but till then the seeds remain as in vacuo, and are theref.re not liable to change.

This deposit of seed mast have bappened in most remote antiquity, 
antiquity, either when the hill country, like the low lands, formed part of an extenisive forest; or more probably when these extensive downs were subject to the plongh.

Being solicitous to know whether these seeds were antediluvian, I took earth from different depths, and soon got below the stratum in which these seeds are found.

The necessity of air for the vegetation of seeds will account for effects which in agriculture are too frequently observed.

If soon after wheat or barley has been sown on what is called a running sand there fallis a dashing rain, the sand runs together, that is, it forms a crust, which in a great measure is impervious to air, and scarcely a grain of corn will grow; or if on clay land, during a time of drought, a garden plot is watered, and left exposed to the scorching beams of a meridian sun, the ground will bake, that is, the surface will be hardened, and being thus rendered impervious to air, vegetation ceases. But if the surface has been previously covered with forn leaves, as practised by skilful and attentive gardeners, no such effect will be produced. The plot may be watered, and recgetation will be rapid.

The admission of air, and its vast importance to the growth of plants, will account for the grood effect produced by harrowing ou wheat crops in spring, as lately introduced, and now universally adopted by our best farmers. The good eflect produced is made apparent by the luxuriant growth of peasc, beans, turnips, and cabbages, after they have been hoed; and is at present so well understood, that many agriculturists hoe their turnips twice, and their beans four times, not merely with a view to the destruction of weeds, but because they observe the benefit arising to their crops by the free admission of air into the earth. The palpable advantage of this practice has led many farmers to consider the principles on which the practice has been founded, and to try by experiments how far it can be pushed.

In this pursuit, and satisfied of the benefits to be derived from loosening the surface of the ground contiguous to his crops, the Rev. Mr. Close has given up the broad-cast hus- 
bandry, keeps the boe constantly in motion, and now finds that he has never occasion for a fallow.

But the most astumishing effect produced by giving free admission of air to the roots of wheat was last year exhibited by Mr. Bartley, secretary to the Society of Arts at Bath. In August 1800 he sowed his wheat in rows with thrce feet intervals, and six inches dis'ance from grain to grain. The proportion of seed was two quarts to an acre. The soil was a deep sandy loam, but out of condition, and filled with conch. This wheat was hoed in autumn, hoed again, and earthed up both at Christmas and spring. When it was in bloom the intervals wcre dug up, and it was once more earthed up. At harvest this crop yelded sixty-six bushels per acre. Such was its luxuriancy, that many of the plants produced 98 perfect cars, many of which, nine inches long, contained each 100 grains.

In the broad cast husbandry of the hill counties of Wilts and Hants, the produce was formerly three or at most four for one, as it was in the greatest part of France. By the drill, without hocing, the return would not be near so much; but in Mr. Bartley's crop we see more than 1000 for 1 ; and some grains yicked nearly ten times as much*.

I shall make but one obervation more upon this subject, which is, that an orchard planted on the green sward requires double the time for its maturity as one on cultivated land, that has a more plentiful supply of air admutued to its roots.

Thus we see that all the great agonts in wature are concerned in the process of vcgetation, and may be considered as the food of plants. But to deternme in what manner each contributes to nutrition, must be left to the investigation of succecding generations.

\section{Letter}

- It must ever be with reluctance that an exception can be taken against any argument of so able a writer as the prezent, especially in a matter of alleged fact. But in thin instance it serms proper to rentark, that the argument drawn from the reported success of Mr. Burtly should be received with cantion, on account of the peculiarivy of the soil;--that soil bing remarkably deep, fat, and productive, and within the linits of a numeryman's garden, near a city abounding with manure, are circumstances not common to other 